\title{
Sickle Cell Gene (HbS) Scenario in Tribal India \\ BP Urade*
}

Anthropological Survey of India, Central Regional Centre, Nagpur- 440006, India

\begin{abstract}
In India, a very high prevalence of sickle cell trait (SCT) has been reported from central, southern and western states, the frequency ranges from 0 to $48 \%$ with sporadic cases in eastern and north-western states. Of the total 6675 screened individuals for haemoglobin S (HbS) from Maharashtra, Kerala and Orissa, 748 samples of eight tribal populations were considered for present study.

A very high frequency of $20.3 \%$ has been observed for $\mathrm{HbS}$ among the Pardhan followed by the Gond (15.7\%) and the Gowari (7.3\%). The Banjara and the Halba show a similar pattern of $\mathrm{HbS}$ distribution being $5.9 \%$ and $5.04 \%$ respectively. The gene is found to be completely absent among the Mana of the same region. The Khutia khond of Orissa state show a lowest frequency for $\mathrm{HbS}$ gene $(0.9 \%)$ of all the studied tribal groups. The Mullukuruman exhibits moderate frequency of $10.8 \%$ as compared to other tribal groups in southern India.

The tribal people of central and southern had a geographical unicentric origin and had unicentric origin of the mutated gene when these tribal populations were in direct contact and underwent panmixia or gene flow. But now they dispersed and live distantly isolating themselves and maintain strict endogamy leading to high frequency for $\mathrm{HbS}$ gene.
\end{abstract}

Keywords: Sickle cell trait; Haemoglobin S; Frequency; Tribal groups; Endogamy; Unicentric origin; Maharashtra; Kerala; Orissa; India

\section{Introduction}

FBecause of its bio-diversity that exists within and between populations, the Indian subcontinent offers unique opportunity for genetic and anthropological studies that throw light on various aspect of human being. Indian tribal populations constitute $8.2 \%$ of the total population [1]. Sickle cell anaemia is an autosomal genetic disorder caused by a defect in HBB gene $(\beta 6 \mathrm{Glu} \rightarrow \mathrm{Val})$. The beta $(\beta)$ globins gene is located on short arm (i.e., P-arm) of chromosome 11 and there are over 475 allelic variants. HbS (Haemoglobin S) is responsible for sickle cell disease, one of the most prevalent genetic diseases, affecting millions of people in India. Individuals who are sickle cell carriers are referred as sickle cell trait and do not express symptoms of sickle cell disease. Either double copy of the HbS variant on both the chromosomes or one copy of $\mathrm{HbS}$ and one copy of $\mathrm{HbC}$ variant on different chromosomes results into disease manifestation. In addition SCD results in combination with mutation for beta thalassaemia on other chromosome.

The presence of Sickle Cell Trait (SCT) provided a selective advantage in hyper endemic malarial areas [2]. The sickle cell gene in homozygous condition was found to be lethal in Africa [2], the homozygous apparently suffer from severe anaemia and die before attaining reproductive age without contributing to the gene pool of the population. Majority of the children born with SCA die before the age of 5 years. Haldane in 1949 described the role of balanced polymorphism for high incidence of SCD in Africa. The incidences of SCT are higher among the tribal groups than other caste populations [3].

Prof. James Herrick of Chicago was discovered and elongated sickle shaped red blood cell in 1910. Subsequently, Huck in 1923 showed that SCD was inherited as a simple Mendelian dominant. It was found that the trait was present to the extent of about $10 \%$ in African origins. The absence in other racial group led to the belief that sickling was an exclusively an African gene. Lehman and Cutbush [4] reported the presence of the trait in considerable frequencies in some of the tribal populations in and around Nilgiri Hills in South India. Buchi [5] was of the opinion that "the sickle cell cannot be a character of Weddis as a whole". He further pointed out that "the possibility of direct contact with the African for the introduction of the trait in India than independent mutation". SCD is by no means an African characteristic alone. Ingram [6] obtained the molecular change in the haemoglobin molecule of SCD -

Chemical structure Position of amino acid

$$
\text { Normal HbA } \quad \mathrm{H}_{3} \mathrm{~N}-\mathrm{Val}-\mathrm{His}-\mathrm{Leu}-\mathrm{Thr}-\mathrm{Pro}-\mathrm{Glu}-\mathrm{Glu}
$$$$
\text { Sickle HbS } \quad \mathrm{H}_{3} \mathrm{~N}-\mathrm{Val}-\mathrm{His}-\mathrm{Leu}-\mathrm{Thr}-\text { Pro - Val - Glu }
$$

Sickle cell disease is generally known by its prevalence in African and American origins. The hypothesis that falciparum malaria is mainly responsible for the maintenance of high frequencies of this trait is widely accepted. One of the evidence presented by Allison [2] in support of this hypothesis is that the distribution of hyper endemic falciparum malaria in Africa holds good for India too [7]. In India also, sickle cell trait is generally found in regions where malaria is present or was still present till recent time. Lower mortality risk is associated with $\mathrm{HbAS}$ due to its protection against malarial related mortality [8].

\section{Material and Methods}

A massive screening programme was conducted for haemoglobinopthies to identify high risk population and to create community awareness followed by counseling to the affected individuals/ families about sickle cell disease for its prevention and management. Several camps were organized in various schools and community halls during July 2005-December 2007 in three states namely Maharashtra (Western India), Kerala (Southern India) and Orissa (Eastern India)

${ }^{*}$ Corresponding author: BP Urade, Anthropologist (Physical), Anthropological Survey of India, Central Regional Centre, Nagpur- 440006, India; E-mail: druradebp@gmail.com

Received March 30, 2012; Accepted July 09, 2012; Published July 16, 2012

Citation: Urade BP (2012) Sickle Cell Gene (HbS) Scenario in Tribal India. J Health Med Inform 3:114. doi:10.4172/2157-7420.1000114

Copyright: (C) 2012 Urade BP. This is an open-access article distributed under the terms of the Creative Commons Attribution License, which permits unrestricted use, distribution, and reproduction in any medium, provided the original author and source are credited. 
of India during which 6675 unrelated individuals comprising 3572 males and 3103 females were screened for Haemoglobin S (HbS) using solutions of qualitative solubility test. Necessary consents approved by the Ethical Committee of Anthropological Survey of India were obtained from individuals before subjecting them to the tests. In order to exclude any bias, the data was strictly adhered to indigenous population of unrelated and healthy individuals and free from any kind of ailment. Out of 6675 samples, Halba (139); Gond (230); Pardhan (64); Mana (31); Gowari (55); Banjara (17) from Maharashtra and two primitive tribal groups Mullukuruman (102) from Kerala and Khutia Khond (110) from Orissa state were considered for present study. The age of the subjects of both males and females ranges from $<9$ to 42 years (Table 1). $20 \mu \mathrm{l}$ blood samples were drawn from finger prick for test and mixed thoroughly with solutions and readings were taken following WHO's guidelines. $2 \mathrm{ml}$ intravenous blood from positive sample was drawn in BD Vacutainer (USA) and brought to the DNA lab at CRC, Nagpur for further analysis. Laboratory investigations were carried out following standard procedure described by Dacie and Lewis [9]. All the samples were subjected to haemoglobin electrophoresis using cellulose acetate membrane in alkaline TEB buffer at $\mathrm{pH} 8.9$ for pattern confirmation. The known samples (control) of $\mathrm{HbS}$ along with present samples were run for electrophoresis. DNA has been extracted from all HbS samples for its genomic study.

\section{Results and Discussion}

The age and sex wise distribution of sickle cell trait (SCT) is given in table 1 . The highest frequency of SCT was found among the Pardhan (20.3\%) followed by the Gond and the Mullukuruman being 15.7 and $10.8 \%$ respectively. The Gowari show the frequency of $7.3 \%$ for SCT while in Banjara and Halba it is found to be 5.9\% and 5.0\% respectively in western India. The Khutia Khond from eastern India, however, found to be lowest $(0.9 \%)$ for $\mathrm{HbS}$ gene. Interestingly, SCT is found to be completely absent among the Mana community belonging to western India. However, the magnitude of SCT was found to be higher among the Pardhan of all the studied tribal groups (Table 1). The wide spread Pardhan in central and western India and few pockets of southern India exhibits more or less a similar pattern with earlier studies for sickle cell indicating stable frequency of the $\mathrm{HbS}$ gene irrespective of time and region (Table 2). Similarly, a very high frequency of $\mathrm{HbS}$ gene has been reported among various tribe like Gond, Kolam, Madia, Halba, Irula, Kurumba, Koya Dora, Panka and
Otkar with varying degrees across the country. The Mullukuruman of the present study exhibit moderate frequency of $10.8 \%$ as compared to other tribal groups in southern India e.g., Adiyan, Yerava, Soliga, Betta Kuruba, Mullukrumba etc. It is found that the Mullukuruman exhibits higher frequency of sickle cell gene than the Kurichian but lesser than the Paniyan and Adiyan of the Wynad district in Kerala state. Sickle cell anaemia in the hilly, forested and once-malarial Wynad district was prevalent among two social groups- the tribal people, particularly the Paniyan and the Kattunayakan and the Wynadan Chetty, a small agriculture caste group, classified among the other backward castes.

The Panka shows highest incidences (48.6\%) of SCT followed by Halba (27.3\%), San-Bhatra (19.3\%) and Bison-horn Maria (18.6\%) amongst the tribal group of Chhattisgarh [7]. The Gond has similar high frequency of the trait (15.1 to $20.5 \%$ ), the Kanwar who are in no way related to Gond show a low frequency of the trait (3.3\%). This is in conformity with the findings of Negi [10]. The frequency of the Kanwar is comparable to that found in the Binjwar, the Manjwar, the Dhanwar and the Kamar of Chhattisgarh (Table 2). The trait was introduced into the Kanwar through Raut and Cherwa by means of hybridization [11].

The Otkar, the Pawar, the Bhill, the Madia Gond, the Madia, the Kolam and the Halbi tribal groups of the eastern Vidarbha region show a very high frequency of $\mathrm{HbS}$ gene [3,12-14]. Table 2 portrays more than $30 \%$ of the $\mathrm{HbS}$ gene among the tribes of central India viz., the Pardhan, the Otkar, the Panka, the Bhilala , the Dhanka and the Garasia in western India, and the Irula in southern India. Above $25 \%$ of the gene HbS was found among the Powar (Maharashtra), the Halba (Chhattisgarh), the Koya Dora (Andhra Pradesh), and the Gamit (Gujarat). The Warli, the Dhodia, the Madia Gond, the Kolam (Maharashtra), the KurumbaJenu, the Kurumba-Beta, the Soliga (Karnataka), the Gond (Madhya Pradesh), the Hill Maria (Chhattisgarh), the Paniyan, the Kurumba (Tamil Nadu) have been reported more than $20 \%$ of sickle cell trait. It is evident from the Table 2 that the frequency of sickle cell trait is higher in southern Indian states i.e., Tamil Nadu, Karnataka, Andhra Pradesh, Kerala, followed by central India i.e., Chhattisgarh, Madhya Pradesh, and western India i.e., Maharashtra, Gujarat and Rajasthan.

In India, a very high prevalence of $\mathrm{HbS}$ gene has been reported in different tribal groups from central, southern and western India, the frequency ranges from 0 to $48 \%$ with sporadic cases in eastern and north-western states. The tribal populations from 9 states depict a very

\begin{tabular}{|c|c|c|c|c|c|c|c|c|c|c|}
\hline \multirow[t]{2}{*}{ Population } & \multirow[t]{2}{*}{$\mathbf{N}$} & \multirow[t]{2}{*}{ Sex } & \multicolumn{8}{|c|}{ Age cohort } \\
\hline & & & $5-9$ & $10-14$ & $15-19$ & $20-24$ & $25-29$ & $30-34$ & $35+$ & Total (\%) \\
\hline \multirow[t]{2}{*}{ Banjara } & 17 & $M$ & - & - & 1 & - & - & - & - & $1(5.9)$ \\
\hline & & $\mathrm{F}$ & - & - & - & - & - & - & - & - \\
\hline \multirow[t]{2}{*}{ Gond } & 230 & M & - & 11 & 9 & 1 & - & - & - & $21(9.1)$ \\
\hline & & $\mathrm{F}$ & 1 & 6 & 6 & 1 & - & 1 & - & $15(6.5)$ \\
\hline \multirow[t]{2}{*}{ Gowari } & 55 & M & - & 1 & 1 & - & - & - & - & $2(3.6)$ \\
\hline & & $F$ & - & 1 & 1 & - & - & - & - & $2(3.6)$ \\
\hline \multirow[t]{2}{*}{ Halba } & 139 & $M$ & - & 1 & 1 & - & - & - & 1 & $4(2.9)$ \\
\hline & & $\mathrm{F}$ & - & 2 & 3 & - & - & - & & $3(2.2)$ \\
\hline \multirow[t]{2}{*}{ Khutia Khond } & 110 & $M$ & - & - & - & - & - & - & - & - \\
\hline & & $F$ & - & - & - & - & - & 1 & 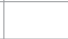 & $1(0.9)$ \\
\hline \multirow[t]{2}{*}{ Mana } & 31 & $M$ & - & - & - & - & - & - & - & - \\
\hline & & $\mathrm{F}$ & - & - & - & - & - & - & - & - \\
\hline \multirow[t]{2}{*}{ Mullukuruman } & 102 & M & - & - & 1 & 2 & 2 & - & - & $5(4.9)$ \\
\hline & & $F$ & - & - & 2 & - & - & 1 & 3 & $6(5.9)$ \\
\hline \multirow[t]{2}{*}{ Pardhan } & 64 & $M$ & - & 1 & 2 & - & - & - & 1 & $5(7.8)$ \\
\hline & & $\mathrm{F}$ & - & 4 & - & 2 & 1 & - & 1 & $8(12.5)$ \\
\hline
\end{tabular}

Table 1: Distribution of sample for $\mathrm{HbS}$ by age and sex. 


\begin{tabular}{|c|c|c|c|c|c|c|c|c|}
\hline Community & Place & Category & No. & AA & AS & SS & $\%$ AS & Source \\
\hline \multicolumn{9}{|l|}{ Maharashtra } \\
\hline Warli & Thane & ST & 128 & - & - & - & 19.53 & \\
\hline Dhodia & Maharashtra & ST & 65 & - & - & - & 21.54 & \\
\hline Konkana & Maharashtra & ST & 83 & - & - & - & 3.61 & \\
\hline Pardhan & Nanded/ Yeotmal & ST & 146 & 97 & 49 & - & 33.56 & \\
\hline Pardhan & Vidarbha & ST & 38 & & & $=$ & 31.6 & \\
\hline Kolam & Vidarbha & ST & 28 & & & 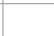 & 20.3 & \\
\hline Raj Gond & Vidarbha & ST & 57 & & 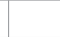 & 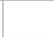 & 11.7 & \\
\hline Naikgond & Vidarbha & ST & 11 & & & - & 10.6 & \\
\hline Otkar & Gadchiroli & ST & - & - & - & - & 35 & \\
\hline Pardhan & Yeotmal/ Nanded & ST & - & - & - & - & 16.8 & \\
\hline Pardhan & Yeotmal/ Nanded & ST & - & - & - & - & 33.7 & \\
\hline Pawara & Dhule, Jalgaon & ST & - & - & - & - & 25.2 & \\
\hline Madia Gond & Gadchiroli, & ST & - & - & - & - & 20.8 & \\
\hline Bhil & Nandurbar & ST & - & - & - & - & 20.6 & \\
\hline Halbi & Gadchiroli & ST & - & - & - & - & 13.9 & \\
\hline Malhar koli & Thane & ST & - & - & - & - & 13.9 & \\
\hline Rajgond & Gadchiroli & ST & - & - & - & - & 10.9 & \\
\hline Korku & Amravati & ST & - & - & - & - & 9.49 & \\
\hline Tandvi & Jalgaon & ST & 72 & - & - & - & 8.33 & \\
\hline Kolam & Yeotmal & ST & 36 & - & - & - & 8.33 & \\
\hline Warli & Thane & ST & - & - & - & - & 8.04 & \\
\hline Katkari & Pune, Ratnagiri & ST & - & - & - & - & 5.9 & \\
\hline Kokana & Dhule,Nashik & ST & - & - & - & - & 3.5 & \\
\hline Andh & Nanded & ST & - & - & - & - & 1.97 & \\
\hline Mahadeo Koli & Pune, Nashik & ST & - & - & - & - & 0.81 & \\
\hline Madia & Gadchiroli & ST & 140 & 115 & 25 & - & 17.86 & \\
\hline Maria Gond & & ST & 167 & - & - & - & 16.17 & \\
\hline Halba & Nagpur & ST & 139 & 137 & 2 & - & 5.04 & \\
\hline Gond & Nagpur/Gondia & ST & 230 & 203 & 27 & - & 15.65 & \\
\hline Banjara & Vidarbha & ST & 17 & 14 & 1 & 1 & 5.88 & \\
\hline Mana & Nagpur & ST & 31 & 31 & - & - & 0 & \\
\hline Gowari & Gondia/Yeotmal & ST & 55 & 51 & 4 & - & 7.27 & \\
\hline Pardhan & Nagpur & ST & 64 & 51 & 13 & 1 & 20.31 & \\
\hline \multicolumn{9}{|l|}{ Chhattisgarh } \\
\hline Binjwar & Raipur & ST & 14 & 14 & & & 0 & \\
\hline Binjwar & Bilaspur & ST & 13 & 12 & 1 & - & 3.85 & \\
\hline Dhanwar & Bilaspur & ST & 31 & 31 & & & 0 & \\
\hline Gond & Raipur & ST & 157 & 132 & 25 & & 7.96 & \\
\hline Gond & Raipur & ST & 63 & 44 & 19 & & 15.08 & \\
\hline Gond & Bilaspur & ST & 129 & 104 & 25 & & 9.69 & \\
\hline Gond & Ambikapur & ST & 127 & 101 & 26 & & 10.24 & \\
\hline Gond-Bade Bhatra & Bastar & ST & 153 & 138 & 25 & & 16.34 & \\
\hline Bison Horn Maria & Bastar & ST & 442 & 360 & 82 & & 18.55 & \\
\hline Bison Horn Maria & Bilaspur & ST & 218 & 171 & 47 & & 10.78 & \\
\hline Dhurwa & Bastar & ST & 60 & 50 & 10 & & 16.67 & \\
\hline Dhurwa & Bastar & ST & 348 & 336 & 12 & & 3.45 & \\
\hline Gond Muria & Bastar & ST & 143 & 128 & 15 & & 10.49 & \\
\hline Gond Muria & Bastar & ST & 169 & 142 & 27 & & 15.98 & \\
\hline Hill Maria & Bilaspur & ST & 85 & 68 & 17 & & 20 & \\
\hline Gond Raj & Bastar & ST & 70 & 60 & 10 & & 14.29 & \\
\hline San Bhatra & Bastar & ST & 88 & 71 & 17 & & 19.32 & \\
\hline Halba & Bastar & ST & 77 & 56 & 21 & & 27.27 & \\
\hline Halba & Raipur & ST & 33 & 29 & 4 & & 13.32 & \\
\hline Halba & Raipur & ST & 122 & 105 & 17 & & 6.97 & \\
\hline Kamar & Raipur & ST & 21 & 20 & 1 & & 2.38 & \\
\hline Kanwar & Ambikapur & ST & 100 & 100 & - & & 0 & \\
\hline Kanwar & Bilaspur & ST & 91 & 88 & 3 & & 3.3 & \\
\hline Kawar & Ambikapur & ST & 114 & 113 & 1 & & 0.46 & \\
\hline Kawar & Raipur & ST & 72 & 68 & 4 & & 2.78 & \\
\hline
\end{tabular}




\begin{tabular}{|c|c|c|c|c|c|c|c|c|}
\hline Kol & Bilaspur & ST & 10 & 10 & - & & 0 & \\
\hline Manjwar & Bilaspur & ST & 17 & 17 & - & & 0 & \\
\hline Oraon & Bilaspur & ST & 6 & 6 & - & & 0 & \\
\hline Panka & Raipur & ST & 26 & 17 & 9 & & 17.3 & \\
\hline Panka & Bilaspur & ST & 35 & 18 & 17 & & 48.57 & \\
\hline \multicolumn{9}{|c|}{ Madhya Pradesh } \\
\hline Bhilala & Jhabua & ST & 384 & 263 & 121 & & 31.75 & \\
\hline Gond & - & ST & 157 & - & - & - & 15.92 & \\
\hline Kawar & & ST & 72 & - & - & - & 5.45 & \\
\hline Halba & & ST & 122 & - & - & - & 13.93 & \\
\hline Gond & & ST & 127 & - & - & - & 20.47 & \\
\hline Oraon & & ST & 422 & - & - & - & 2.13 & \\
\hline Kawar & & ST & 114 & - & - & - & 0.88 & \\
\hline Bhil & & ST & 145 & - & - & - & 17.24 & \\
\hline Korku & & ST & 102 & - & - & - & 1 & \\
\hline Bhilala & & ST & 977 & D & 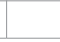 & & 19.04 & \\
\hline \multicolumn{9}{|l|}{ Gujarat } \\
\hline Dhanka & Surat & ST & 30 & 21 & 9 & 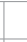 & 30 & \\
\hline Gamit & & ST & 251 & - & - & - & 17.13 & \\
\hline Gamit & Surat & ST & 137 & 103 & 34 & 4 & 25 & \\
\hline Gamit & & ST & 207 & - & - & - & 31.4 & \\
\hline Naik & & ST & 174 & - & - & - & 16.09 & \\
\hline Bhil & & ST & 206 & - & - & - & 15.53 & \\
\hline Dhanka (Bhil) & & ST & 215 & - & - & - & 19.07 & \\
\hline Dhodia & & ST & 213 & - & - & - & 17.84 & \\
\hline \multicolumn{9}{|l|}{ Rajasthan } \\
\hline Garasia & Sirohi & ST & 75 & 50 & 25 & & 33.33 & \\
\hline Garasia & Udaipur & ST & 35 & 24 & 11 & & 31.43 & \\
\hline \multicolumn{9}{|c|}{ Andhra Pradesh } \\
\hline Relli & Vishakapatanam & ST & 138 & 99 & 39 & 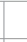 & 14.2 & \\
\hline Pardhan & Adilabad & ST & 101 & 65 & 35 & 1 & 34.65 & \\
\hline Yerukula & & ST & 125 & - & - & - & 0.8 & \\
\hline Yerukula & & ST & 40 & - & - & - & 0 & \\
\hline Savara & & ST & 132 & - & - & - & 1.52 & \\
\hline Jatapu & & ST & 157 & - & - & - & 1.27 & \\
\hline Jatapu & & ST & 260 & - & - & - & 5.94 & \\
\hline Sugali & & ST & 61 & - & - & - & 4.92 & \\
\hline Konda Reddy & & ST & 92 & - & - & - & 2.17 & \\
\hline Koya & & ST & 159 & - & - & - & 12.57 & \\
\hline Raj Gond & & ST & 133 & - & - & - & 14.28 & \\
\hline Koya Dora & & ST & 99 & - & - & - & 24.24 & \\
\hline Koya Dora & & ST & 547 & - & - & - & 7.86 & \\
\hline Naik Pod & & ST & 90 & - & - & - & 4.44 & \\
\hline Lambadi & & ST & 154 & - & - & - & 2.6 & \\
\hline Pardhan & & ST & 122 & - & - & - & 31.79 & \\
\hline Raj Gond & & ST & 197 & - & - & - & 11.17 & \\
\hline Kolam & & ST & 215 & - & - & - & 14.92 & \\
\hline Chenchu & & ST & 139 & - & - & - & 0.72 & \\
\hline Koya & & ST & 238 & - & - & - & 6.58 & Pingle [23] \\
\hline Manne & & ST & 155 & - & - & - & 2.58 & \\
\hline Kolam & & ST & 142 & - & - & - & 7.04 & \\
\hline Raj Gond & & ST & 140 & - & - & - & 14.28 & \\
\hline \multicolumn{9}{|l|}{ Karnataka } \\
\hline Kurumba-Jenu & Coorg & ST & 76 & 46 & 29 & 1 & 20.66 & \\
\hline kurumba-Beta & Coorg & ST & 67 & 39 & 27 & 1 & 21.6 & \\
\hline Soliga & Mysore & ST & 102 & 61 & 40 & 1 & 20.59 & \\
\hline \multicolumn{9}{|l|}{ Kerala } \\
\hline Adiyan & Cannore & ST & 75 & 51 & 24 & & 16 & \\
\hline Paniyan & Kerala & ST & 61 & 40 & 21 & & 17.21 & \\
\hline Mullukuruman & Wynad (Kerala) & ST & 102 & 91 & 11 & - & 10.78 & \\
\hline Adiyan & Cannore & ST & 75 & 51 & 24 & & 16 & \\
\hline
\end{tabular}




\begin{tabular}{|c|c|c|c|c|c|c|c|}
\hline Paniyan & Kerala & ST & 61 & 40 & 21 & & 17.21 \\
\hline Kurichian & Wynad (Kerala) & ST & 106 & 104 & 2 & - & 1.88 \\
\hline Mullukuruman & Wynad (Kerala) & ST & 102 & 91 & 11 & - & 10.78 \\
\hline \multicolumn{8}{|l|}{ Tamil Nadu } \\
\hline Paniyan & Nilgiri & ST & 109 & 62 & 45 & 2 & 22.47 \\
\hline Irual & Nilgiri Hills & ST & 124 & 85 & 39 & & 15.73 \\
\hline Irual & Nilgiri Hills & ST & 254 & 168 & 81 & 5 & 17.91 \\
\hline Irual & Nilgiri Hills & ST & 130 & 84 & 46 & & 35.38 \\
\hline Kurumba-Mullu & Nilgiri & ST & 101 & 62 & 38 & 1 & 19.8 \\
\hline Toda & & ST & 98 & - & - & - & 1.02 \\
\hline Kurumba & & ST & 43 & - & - & - & 20.93 \\
\hline Toda & & ST & 60 & - & - & - & 3.33 \\
\hline Irula & & ST & 15 & - & - & - & 40 \\
\hline Kurumba & & ST & 43 & - & - & - & 23.25 \\
\hline Kota & & ST & 549 & - & - & - & 0 \\
\hline Irula & & ST & 175 & - & - & - & 26.28 \\
\hline Irual & Nilgiri Hills & ST & 124 & 85 & 39 & & 15.73 \\
\hline Irual & Nilgiri Hills & ST & 254 & 168 & 81 & 5 & 17.91 \\
\hline Irual & Nilgiri Hills & ST & 130 & 84 & 46 & & 35.38 \\
\hline Kurumba-Mullu & Nilgiri & ST & 101 & 62 & 38 & 1 & 19.8 \\
\hline Toda & & ST & 98 & - & - & - & 1.02 \\
\hline Kurumba & & ST & 43 & - & - & - & 20.93 \\
\hline Toda & Nilgiri & ST & 60 & - & - & - & 3.33 \\
\hline Irula & Nilgiri & ST & 15 & - & - & - & 40 \\
\hline Kurumba & Nilgiri & ST & 43 & - & - & - & 23.25 \\
\hline Kota & & ST & 549 & - & - & - & 0 \\
\hline Irula & & ST & 175 & - & - & - & 26.28 \\
\hline \multicolumn{8}{|l|}{ Orissa (Odisha) } \\
\hline Gadaba-Ollaro & Koraput & ST & 225 & 218 & 7 & 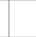 & 3.11 \\
\hline Khutia khond & Phulbani dist & ST & 110 & 109 & 1 & - & 0.91 \\
\hline Bado Gadaba & Koraput & ST & 100 & 100 & - & - & 0 \\
\hline Baren Paroja & Koraput & ST & 100 & 100 & - & - & 0 \\
\hline Kondh & & ST & - & - & - & - & 5.5 \\
\hline Kutia kondh & & ST & - & - & - & 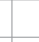 & 1.7 \\
\hline Oraon & & ST & - & - & - & - & 0.2 \\
\hline Saora & & ST & - & - & - & & 0.2 \\
\hline Santal & & ST & - & - & - & - & 0 \\
\hline \multicolumn{8}{|l|}{ Bihar } \\
\hline Oraon & & ST & 130 & & & & 0.77 \\
\hline Oraon & & ST & 56 & & & & 0 \\
\hline \multicolumn{8}{|l|}{ West Bengal } \\
\hline Santhal & & ST & 336 & 4 & - & - & 1.19 \\
\hline Santhal & & ST & 164 & 0 & - & - & 0 \\
\hline Oraon & & ST & 204 & 2 & - & - & 0.98 \\
\hline Kaora & & ST & 202 & 1 & - & - & 0.5 \\
\hline
\end{tabular}

Table 2: Community and state wise frequency distribution of sickle cell trait.

high percentage of incidences of $\mathrm{HbS}$ gene. The frequency of $17.2 \%$ among the Paniyan for HbS gene starts from Kerala of southern India goes up to $48.6 \%$ among the Panka in Chhattisgarh and then follows a declining trend to western and north-western states of Gujarat and Rajasthan. One of the reasons for occurring in such a high incidences could be attributed to the practice of consanguinity among most of them and the similar findings were reported by Mukherjee and Das [15]. But it is surprising to note that why the other neighboring populations who live in the similar ecological niche do not exhibit similar trend for the SCT? In some of the tribal groups the HbS gene is completely absent. The Khutia khond, the Korku, the Chenchu, the Oraon, the Kolam, the Lambadi, the Halba, the Kawar, the Andh, the Toda, the Savara, the Jatapu, the Konda reddy, the Yerukula, the Manne etc., show a negligible frequency for SCT. The frequency of HbS gene was found to very low among the tribes of Orissa, Bihar and West Bengal.

Piel et al. [16] showed the presence of HbS allele frequency of $>0.5 \%$ in the African continent, the Middle East and India. The highest frequency of $\mathrm{HbS}$ allele in tribal groups of India indicates a similar pattern of prevalence of SCT from southern Senegal to northern Liberia to southeast Tanzania to Saudi Arabia up to Chhattisgarh and southern Karnataka region of India. Mukherjee and Das [15] are of the view that the highest gene frequency of $\mathrm{HbS}$ occur in region where malaria is highly endemic. HbS was largely absent in the areas of Horn of Africa and south of the Zambezi. Piel et al. [16] shown a similar pattern of distribution of $\mathrm{HbS}$ frequency in malaria-free, hypoendemic 
and mesoendemic zones but higher in hyperendemic and holoendemic areas. In Asia, no relation between $\mathrm{HbS}$ allele frequency and malaria endemicity was found. Globaly, the HbS frequency increases with the increase in malarial endemicity but a reverse trend has been noticed in Asia.

Based on the high magnitude of sickle cell, the gene HbS could be located from four zones across India: (1) Tamilnadu, Andhra Pradesh and Karnataka, (2) Chhattisgarh and Madhya Pradesh, (3) Maharashtra, Gujarat and Rajasthan and (4) Kerala, besides sporadic occurrence of gene in Orissa, Bihar and West Bengal. The concentration of HbS gene is in southern and western states spreading across the country with intermediate frequencies in the neighboring state and slow down it in farther states. From this two inferences can be drawn, 1. The mutation for $\mathrm{HbS}$ gene has taken place independently in different populations during the course of time and/or 2. The lethal gene $\mathrm{HbS}$ has introduced in India through southern and western sea-routes during ancient time as the frequency of $\mathrm{HbS}$ is higher in those corresponding states.

Rao et al. [17] had shown a trimodal distribution of HbS concentrations among the tribes of Maharashtra. Many tribal groups practice area inbreeding and the deleterious gene may be confined within the smaller endogamous groups that maintain more or less a stable frequency among them as the pattern of SCT was found to be same reported by earlier studies.

\section{Conclusion}

The tribal people of central and southern had a geographical unicentric origin and had unicentric origin of the mutated gene when these tribal populations were in direct contact and underwent panmixia or gene flow. But now they dispersed and live distantly isolating themselves and maintain strict endogamy leading to high frequency for HbS gene. A high frequency of SCT was reported among the food gatherers and jhoom/slash burn agriculturist in India [18]. But the distribution pattern of HbS does not conform to the earlier studies as the $\mathrm{HbS}$ in high frequencies is prevalent among the tribes with varied life styles. For example, the Pardhan, the Gowari, the Bhilala and the Gamit are agriculturist; the Irula is an artisan; the Kurumba, the Madia, are hunting tribes and the Banjara is a nomad, show equally high frequencies of HbS amongst them. On the contrary, the Mana is an agriculturist, the Halba is weaver and the Khutia khond is hunters and gatherers show a complete absence or negligible $\mathrm{HbS}$ gene.

Lehman and Cutbush [4] first detected the sickle cell gene among the Irula of Nilgiri Hills in South India. The frequency of this lethal gene varies from complete absence to $48.57 \%$ among the tribal population which is quite alarming as compare to other ethnic groups in India. Once upon a time the Mullukuruman were hunters and gatherers but now they are settled agriculturist. The moderate frequency of $10.78 \%$ sickle cell gene among the Mullukuruman justify the hypothesis put forward by Allison. On the contrary, some tribal groups whose economy is still depend on hunting and gathering and some of them are settled agriculturist but do not have high incidences of sickle cell trait and in some of them the trait is completely absent. The Allison hypothesis says that the sickle cell trait shows its presence in the hyper endemic region of falciparum malaria and the population whose economy revolves around agriculture and settled population. A correlation between sickle cell trait and malarial endemicity has been found among some populations of central India and Maharashtra $[19,20]$. But how far the malarial hypothesis is tenable for the spread of sickle cell among different populations need in-depth study in Indian context as the prevalence of SCT is not uniform across the country where the malaria still exist.
$\mathrm{HbS}$ is in some of the indigenous populations of northern India, eastern India and north east India the $\mathrm{HbS}$ gene is either completely absent or present in very low frequency. Therefore, the malaria-sickle cell hypothesis does not hold well in India so far as the occurrences of $\mathrm{HbS}$ in different indigenous tribal as well as caste groups in varied ecological zones are concerned. In India most of the part are highly malarial endemic, despite this $\mathrm{HbS}$ is absent in more than half of its region.

\section{References}

1. http://censusindia.gov.in/2011-common/censusdataonline.html

2. Allison AC (1954) Protection afforded by sickle cell trait against subtertian malarial infection. Br Med J 1: 290-294

3. Urade BP (2008) Haemoglobinopathies in Vidarbha region of Maharashtra. Presented a Paper in a National Conference (March, 7-9, 2008) on Prevention of Beta-thalassaemia in India, at Anthropological Survey of India, Head Office Kolkata.

4. Lehman H, Cutbush M (1952) Sickle cell cell trait in Southern India. Br Med $J$ 1: 404-405.

5. Buchi EC (1955) Is sickling a Weddid trait? The Anthropologist 2: 25-29

6. Ingram VM (1957) Gene mutations in human haemoglobin: the chemical difference between normal and sickle cell haemoglobin. Nature 180: 326-328.

7. Negi RS (1976) Population dynamics of sickle cell traits distribution in India Ph.D Thesis (Unpublished) University of Calcutta.

8. Aidoo M, Terlouw DJ, Kolczak MS, McElroy PD, Ter Kuile FO, et al. (2002) Protective effects of the sickle cell gene against malaria morbidity and mortality. Lancet 359: $1311-1312$.

9. Dacie JV, Lewis SM (1977) Practical haematology. Churchill Livingstone Scotland.

10. Negi RS (1964) New Incidence of Sickle-Cell Trait in Bastar, III. Man 64: 214.

11. Negi RS (1963) ABO blood groups, sickle cell trait and colour blindness in the maria of Bastar and Gond and Kanwar of Bilaspur. Bull Anthro Sur Ind 12 149-153.

12. Banker MP, Kate SL, Mokashi GD, Khedkar VA, Phadke MA (1984) Distribution of sickle cell haemoglobin among different tribal groups in Maharashtra. Ind $J$ Heamatol.

13. Kate SL (2001) Health problems of tribal population groups from the State of Maharashtra. Indian J Med Sci 55: 99-108.

14. Urade BP, Chakravarty M, Mallick SK (2008) Sickle cell anaemia: a genetically handicap disease. In. Bio-social Issues in Health (Eds.) R. K. Pathak, A. K. Sinha, B. G. Banerjee, R. N. Vasishat and C. J. Edwinn, Northern Book Centre 47-55.

15. Mukherjee BN, Das MK (1990) Spatial distribution of two predominant abnorma haemoglobins - $\mathrm{HbE}$ and $\mathrm{HbS}$ in Indian subcontinent. J Indian Anthrop Soc 25 $39-59$

16. Piel FB, Patil AP, Howes RE, Nyangiri OA, Gething PW, et al. (2010) Global distribution of the sickle cell gene and geographical confirmation of the malaria hypothesis. Nat Commun 1: 104.

17. Rao VLN, Reddy GG, Busi BR (1986) A1A2BO, Rh (D) and sickle cell trait among Jatapu of Andhra Pradesh. Ind J Phy Anth \& Hum Genet 12: 81-84.

18. Harrison GA (1988) Population variation in qualitative traits (protein). In Human Biology (Eds.) G.A. Harrison, J.M. Tanner, D.R. Pilbeam and P.T. Baker, Oxford University Press, oxford, 231-235

19. Deshnukh VV (1968) Deficiency of erythrocyte glucose-6-phosphate dehydrogenase and sickle- cell trait;a survey at Aurangabad, Maharastra. Ind J Med Res 56: 821-825.

20. Mukherjee BN, Malhotra KC, Das RK, Bandopadhyay HS, Kate SL (1982) Spatial and social variation in sickle cell trait, G6PD deficiency and malaria in north Maharashtra: A preliminary report. In Human Genetics and Adaptation Vol 1 (Eds) K C Malhotra and Amitabha Basu Proc ISI Golden Jublee Con 225-333. 